\title{
Implementation of the Itsbat of Marriage in Terms of Law Number 1/1974 and Compilation of Islamic Law
}

\author{
Maskawati $^{1}$, Sitti Harlina Hamid ${ }^{2}$, Burhanudin ${ }^{3}$ \\ ${ }^{1,3}$ Department of Law, Institut Agama Islam Negeri Bone, Indonesia \\ ${ }^{2}$ Department of Law, Universitas Islam Makassar, Indonesia
}

\begin{abstract}
This study evaluates the implementation of marriage rituals at the Watansoppeng Religious Court following Law Number 1/1974 and the Compilation of Islamic Law. It evaluates the basis for judges' considerations in deciding marriage cases at the Watansoppeng Religious Court. This research is qualitative research with purposive sampling, and data collection techniques used are field research and library research. The data analysis technique was analyzed qualitatively, then described descriptively by explaining, describing, and describing the problems closely related to this research - the need to provide information and counseling to the community on an incentive basis. Counseling regarding the contents of Law Number 1/1974 concerning marriage, counseling on the importance of marriage registration for life to come, especially for their children and the assets they gain in marriage. This counseling is given to all levels of society, especially rural communities, both married and unmarried. The purpose of marriage to form an eternal family based on the Almighty God is achieved.
\end{abstract}

Keywords

Implementation; marriage; isbat; islamic law

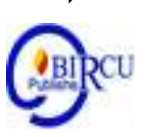

\section{Introduction}

Married means to compile or collect. Efforts to channel married couples into the household and obtain offspring can ensure the continuity of human existence on earth. The presence of marriage is in line with humans' birth on earth and is a human nature given by Allah SWT to His servants. Marriage is one of Prophet Adam AS's teachings, carried on in Prophet Muhammad SAW's teachings, and is highly recommended for his followers with various expressions. One of them is the Prophet Muhammad's saying:

From Anas RA, some of the Prophet SAW companions secretly asked the Prophet SAW's wives about his deeds of worship. Then some of them said: I will not marry a woman. Another said: I will not eat meat. And yet another says: I will not sleep on a pedestal. Hearing that, the Prophet (PBUH) asked Allah and said: what do those who say this want! Even though I prayed and slept, fasted and broke and married a woman! Whoever does not like my sunnah, then he is not in my group. (HR. Muslim).

This hadith shows that marriage is the sunnah of the Prophet Muhammad. Marriage is required so that human descendants and legitimate families lead a happy life in this world and the hereafter, under the auspices of the love and pleasure of Allah SWT. Because of this marriage problem's importance, there is a need to make rules about it to benefit the spouse and the people beside them. Marriage regulations have been around for a long time. These regulations continue to develop in society; even the marriage rules are no longer limited; Indonesian citizens also depend on citizens whose association with Indonesian citizens is expanding. Marriage and its fair laws in a society or a nation cannot be separated from the influence of culture and the community's environment, and the people's associations. It proves by the knowledge, experience, beliefs, and religions of the 
people. Like the Indonesian nation's marriage regulations, it is the local community's cultural customs and religious teachings' inspiration. In Indonesia, the provisions of marriage have been regulated in special rules for Indonesian citizens. The marriage rules are in Law Number 1/1974 concerning marriage and its implementing Government Regulation Number 9 of 1975. This law is the material law of marriage, while the ceremonial law is stipulated in Law Number 7/1989 Regulations amended by Law Number 3/2006 in conjunction with Law Number 50/2009. Meanwhile, as a complementary rule that will be new for Judges in religious courts is a complication of Islamic Law stipulated and disseminated through Presidential Instruction Number 1 of 1991 about Islamic Law's Complications.

The Indonesian nation already has a national marriage law as a basic rule. However, there are still marriages that are only carried out following the law of religion and their beliefs. This includes rural areas where customary rituals are robust and do not understand the importance of marriage registration. Therefore, after enacting Law Number 1/1974 concerning Marriage and Government Regulation Number 9/1975, there has been a shift regarding the validity of a marriage regulated by religion and belief. Among them, what we have often witnessed and witnessed is a marriage based on Islamic law. According to the provisions of Article 2 Paragraph (1) of Law Number 1/1974, a marriage is said to be valid according to the law of each religion and belief. Meanwhile, marriages carried out outside the supervision of a Marriage Registration Officer do not have legal force (Article 6 Paragraph (1) KHI). It is also emphasized that a marriage can only be proven by a marriage certificate made by a Marriage Registration Officer (Article 7 Paragraph (1) KHI). Thus, according to the Islamic religion, a marriage carried out must be carried out following Islamic law, carried out in the presence of a Marriage Registration Officer, and proven by a marriage certificate.

The marriage certificate becomes clear evidence of marriage's implementation as a legal guarantee against a husband and wife if a deviant act is committed. One example that we often encounter that occurs in Indonesian society is an under-hand marriage. Marriages that are only carried out according to Islamic religious law without registration of the marriage by a Marriage Registration Officer so that a marriage certificate cannot prove it, and according to Law Number 1/1974, this marriage has no legal force because it does not fulfill Article 2 Ayta (2) Law Law Number 1/1974. So that there is a dispute between husband and wife, divorce is only carried out according to Islamic law, but this does not provide legal protection for the woman (wife), that for marriage which is only done according to religious law (Islam), but no data can be obtained by submitting a marriage certificate to the Religious Court. This is confirmed in Article 7 of the Compilation of Islamic Law. In Article 7 Paragraph (3) Compilation of Islamic Law, marriage requests that can be submitted to the Religious Court are limited to matters relating to:

a) To settle a divorce;

b) Loss of marriage certificate;

c) Doubts about whether or not one of the conditions of marriage exists;

d) The marriage occurred before the enactment of Law Number 1/1974 concerning marriage;

e) Marriage is carried out by those who do not have a marriage impediment, according to Law Number 1/1974.

And Article 7 Paragraph (4) states that those who have the right to apply for marriage privileges are husband or wife, children, marriage guardians, and parties interested in the marriage. As in the case of the Makassar Religious Court, cases of marriage rituals also occurred. The purpose of submitting applications varies. Some apply for divorce proceedings, and some are filled with reasons to get pension funds, etc. 


\section{Review of Literature}

\subsection{Islamic Law and Its Scope}

The term Islamic law consists of two words that come from Arabic, namely Islamic Law and Words. The word Law means provisions or provisions, while Islam comes from the word "aslama" to become "salama," which then becomes Islam which means, safe, peaceful, prosperous, or fully surrendered to God. According to Abdurrauf (M.Arifin Hamid, 2011: 41), in terms of terms, the law according to Islamic teachings are regulations consisting of provisions, orders, and prohibitions that give rise to obligations and or rights. Meanwhile, etymologically Islamic law is all kinds of provisions or provisions regarding anything in which the provisions have been regulated and stipulated by the Islamic Religion. In Islam, two terms are usually translated into Islamic law, namely Sharia and Fiqh. Shari'a is the Al-Quran, and the Sunnah of the Prophet can complement all the foundations of religion, morals, human-human relations, even covering the purpose of life and human life for the safety of the world, and the hereafter is.

Meanwhile, Fiqh can be interpreted as laws extracted from the Al-Quran and the Prophet's Sunnah using perfect understanding or ijtihad and deep reflection. According to (M. Daud Ali, 2004: 47), sharia is a fundamental legal norm established by Allah SWT, followed by Muslims based on faith-related to morals, both relationships with Allah SWT and fellow humans in society. Meanwhile, Fiqh is a science whose job is to determine and describe the norms and laws contained in the hadith. The source of Islamic law is the origin from which Islamic law was taken. Allah has decided for himself the basis of Islamic Law which every Muslim must follow in the Al-Quran letter An-Nisa (4) Verse 59, every Muslim is obliged to obey the will or will of Allah SWT in the form of decrees written in the Al-Quran, the choice of the Prophet has written In the hadiths, the will of the ruler is contained in statutory regulations or in the work of a person who qualifies for doing ijtihad. Islamic law has a broad field that differentiates it from other legal systems.

\subsection{Marriage}

According to the original meaning, marriage is sexual relations. According to the majaazi (mathaporic) meaning or the legal meaning, it is a contract (agreement), which makes sexual relations as husband and wife lawful between a man and a woman. Language-based marriage comes from the word married, which begins with "Per" and the suffix "an." Marriage in the large Indonesian dictionary (1993: 456) means: "forming a family with the opposite sex, having a husband or wife, marrying, sex ratio (for animals), and having intercourse, marriage." In terms there are several kinds of definitions of marriage with the same purpose, as stated by Suyuti (2003: 8) that: marriage is making a contract or agreement to bind oneself between a man and a woman to legalize sexual relations between the two parties, based on love, willingness and pleasure of both parties to realize a happy family life which includes a sense of love and peace in ways that are pleased by Allah SWT. According to Mohammad Idris Ramulyo (2004: 1), marriage is marriage, while aqad or commonly known in Indonesian, is called a contract that means agreement. So the marriage contract means a sacred deal to bind oneself in a marriage between a woman and a man to form a happy and eternal (eternal) family. Holy here means having an element of religion or the Supreme Lordship. In connection with this marriage, Muh. Thalib (M. Idris Ramulyo, 2004:2) defines marriage as a physical and spiritual bond between a man and a woman as husband and wife to form a happy and eternal family (household) based on the One Godhead. According to the provisions in Article 1 of law no. 1/1974 concerning marriage, the definition of marriage is The physical 
and spiritual bond between a man and a woman as husband and wife to form a happy and eternal family (household) based on the One Godhead. Furthermore, following the provisions of Article 2 Book I concerning Marriage Law Compilation of Islamic Law (KHI), the definition of marriage has been formulated, namely: "A firm contract or miltsaagon gholiidhan to obey Allah's orders and carry out it constitutes worship. Meanwhile, Article 3 also stipulates that marriage aims to create a sakinah, mawaddah, warahmah household life.

Wedding ceremony is the important event in every human life. Basically, a wedding is a rite of passage, an event that marks a person's transition from one life status (single) to another (married). It can be seen as these stages are reflected as the approach of life event. Ceremony is the kind of formal event, it certainly has the master of ceremony, someone who lead the activity in ceremony. (Purba and Muliyadi, 2020). The only requirement for Muslim weddings is the signing of a marriage contract. Marriage traditions differ depending on culture, Islamic sect, and observance of gender separation rules. Most marriages are not held in mosques, and men and women remain separate during the ceremony and reception. Since Islam sanctions no official clergy, any Muslim who understands Islamic tradition can officiate a wedding. (Jamaluddin, 2018)

Meanwhile, according to Article 2 of the Compilation of Islamic Law, that: "Marriage according to Article 2 of the Compilation of Islamic Law is marriage, which is a firm contract or mitsaaqoon ghollidhan to keep the commands of Allah SWT and carry it out is worship". From the above provisions, it can be seen that the Marriage Law emphasizes the validity of a marriage on two elements, namely: marriage must be carried out following the requirements and procedures determined by law (state law) and religious law. This means that if a marriage is only carried out according to state law provisions without regard to religion, the marriage is invalid, and vice versa. Government participation in marriage activities is in matters relating to administrative processes, where marriage must be recorded as contained in Article 2. The respective religions and religions determine the validity of the marriage itself.

The stages or process of registering a marriage as regulated in Government Regulation Number 9/1975 include:

a. Notifying the marriage's intention to be carried out verbally or in writing by the prospective bride or parent or guardian. The year notification contains the personal identity and is submitted 10 (ten days) before the marriage takes place (articles 4 and 5, Government Regulation Number 9/1975);

b. After all the requirements have been met and there are no obstacles to getting a marriage according to the law, the marriage is entered in the register book and announced. (Articles 6, 7, 8, and 9 of Government Regulation No. 9/1975);

c. After the marriage occurs, the bride and groom must sign a Marriage Certificate that two witnesses and a marriage registrar attend. Meanwhile, for Muslim couples, a marriage certificate is also signed by the guardian of marriage. (Articles 12 and 13 of Government Regulation Number 9/1975);

d. To provide legal certainty to the bride and groom, each submits an excerpt of a marriage certificate as evidence. 


\subsection{Framework}

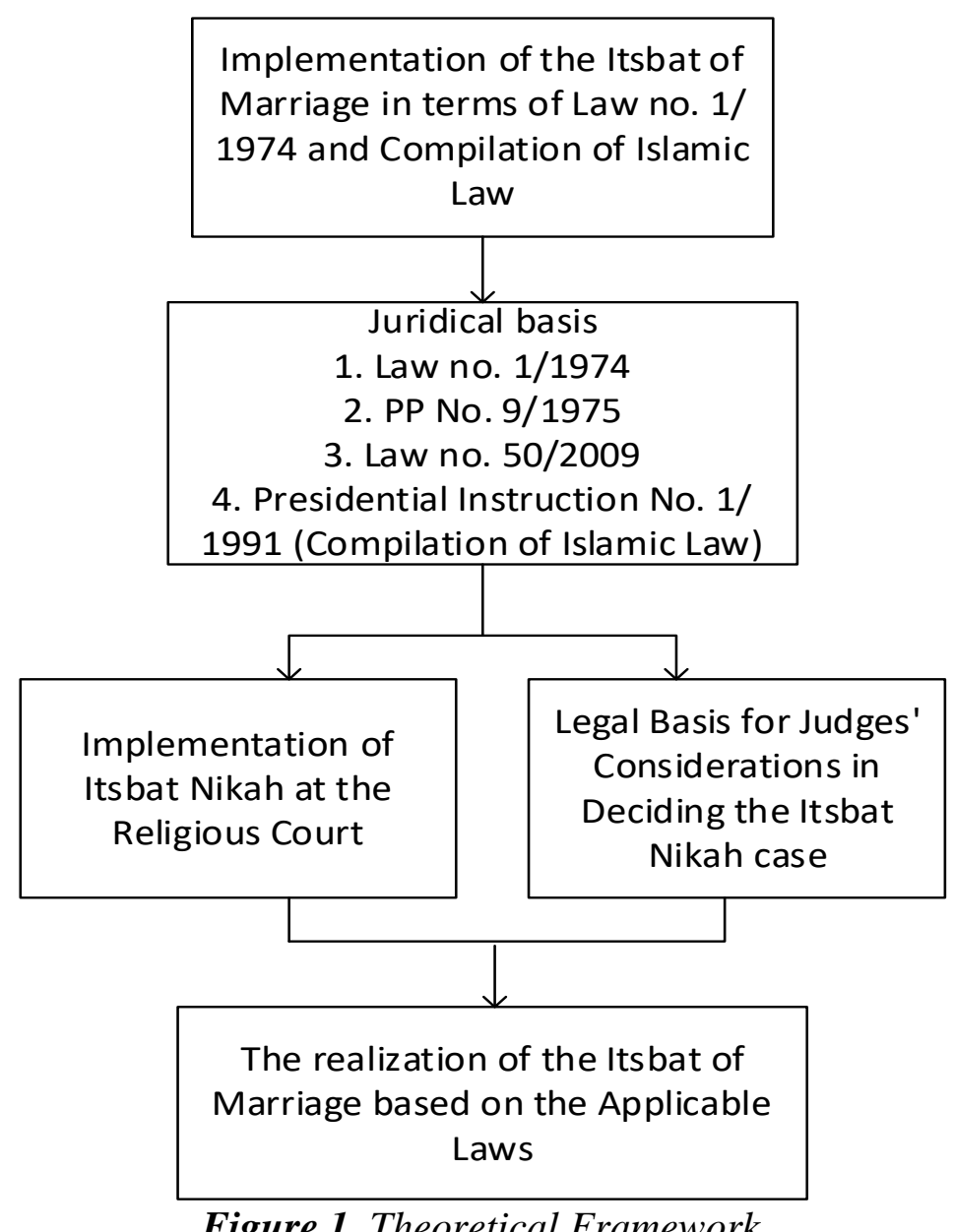

Figure 1. Theoretical Framework

\section{Research Methods}

To lead to the goals to be achieved in a study, defining both the problem and the research location is necessary. The author chose to research Watansoppeng by taking place at the Religious Court. This research's location was selected considering that the institution was related to implementing the marriage certificate. The types and sources of data in this study are primary data and secondary data. Primary data collection was obtained from direct research at the Religious Courts through direct interviews with the judges who handled the marriage case. Secondary data collection is obtained through literature study by collecting data on reports, books, documents, laws and regulations, the internet, and archives at the Watansoppeng Religious Court. The techniques used to collect data in field research and library research. Field research (field research) collects data through field research by conducting direct interviews with the judge handling marriage. Library research, namely data collection techniques by collecting and studying literature, laws, regulations, the internet, archives at the Religious Courts, and relevant documents. The analysis that has been obtained through research activities is analyzed qualitatively, and then described descriptively by explaining, describing, and describing the problems that are closely related to this research. 


\section{Result and Discussion}

\subsection{The implementation of Itsbat Marriage at the Watansoppeng Religious Court in}

terms of Law No. 1 of 1974 and the Complications of Islamic Law.

The rules for ratification of marriage / itsbat marriage are made based on whether or not a marriage is conducted based on religion. The regulations for the legalization of marriage number in Article 46 number (22) the explanation of law 7 of 1989 in conjunction with law number 3 of 2006 in conjunction with law number 50 of 2009 and article 7 paragraphs (2), (3), and (4) compilation Islamic law. This means that the parties to obtain marriage approval even though they do not have a marriage certificate and do not have a marriage in the presence of a marriage registrar employee is a condition that requires that they can apply for a marriage intention. Other rules relating to marriage or legalization of marriage information in the Islamic Law Compilation Article 7 which states that:

1) Marriage can only be proven by a marriage certificate prepared by a marriage registrar;

2) If a marriage certificate cannot prove the marriage, the marriage certificate can be submitted to the religious court;

3) Marital acts submitted to a religious court are limited to matters relating to (a) in the context of settling a divorce, (b) loss of marriage certificate, (c) doubts about whether or not a condition of marriage is valid, (d ) some marriages occurred before the enactment of Law Number 1 of 1974 concerning marriage, (e) marriages that were carried out by those who did not have a marriage impediment according to Law Number 1/1974.

4) Those who have the right to apply for the marriage certificate are the husband or wife, their children, the marriage guardian, and the parties interested in the marriage.

According to Mustamin Dahlan (Judge of the Watansoppeng Religious Court, interview August 1, 2019) in Law Number 1/1974 concerning marriage, it is clear that the marriage carried out must be following the laws of each religion and belief and must be registered by a local marriage registrar. However, in the case of an anonymous marriage or no marriage certificate, Muslims can apply to the Religious Court to legalize the marriage. Legalizing the marriage is carried out by referring to Law Number 1/1974 and the compilation of Islamic Law. Lahiya further explained that even though in Law Number $1 / 1974$, there is no specific explanation regarding the legalization of marriage, this is regulated in the Compilation of Islamic Law, which complements Law Number 1/1974. The following is a brief explanation of the procedure for submitting an application for legalization of marriage or marriage certificate at the Watansoppeng Religious Court:

1) The applicant submits his application to the Religious Court. If the husband and wife are still alive, then the husband becomes Petitioner I, and the wife becomes Petitioner II.

2) The applicant registers the marriage ceremony at table 1 (case or partnership).

3) At table I, the applicant will be given a power of attorney to pay (SKUM).

4) After everything has been given to the applicant, the applicant is obliged to pay the fee, the amount of which is calculated in the SKUM

5) After payment is made, the applicant will be given a case number following the case entered.

6) After being given the sequence number, the receipt and application file are returned to the applicant. To then be submitted to Table II.

7) Then at table II, all copies of the lawsuit or petition submitted will be given.

8) The applicant is given a SKUM along with a copy of the lawsuit or application.

9) All documents received are then given to the Chief Justice through the deputy clerk

10) Then the Chairman of the Court makes (PMH) a decision of the Panel of Judges who will handle the case. 
11) Then the file is submitted to the appointed Panel of Judges.

12) After reading the case, the Panel of Judges determines the day of trial (PHS) by ordering the bailiff to summon the parties to attend the trial.

13) Next is the trial stage.

To know more clearly about the implementation or application of the law, especially the implementation of marriage legalization or marriage certificate at the Watansoppeng Religious Court, as an illustration, the language writer about the example of determining the marriage certificate that was carried out in the Watansoppeng Religious Court is as follows:

\section{Case I: Case Number: 137 /Pdt.P/2016/PASop}

Aminuddin bin Anar, 71 years old, Islam religion, no job, residence on Jalan Wijaya Lrg 2 No.4 Rt 005 Rw 008, Lalabata District, Soppeng Regency, after this referred to as Petitioner I, with Bumbeng Binti Dandi, 69 years old, Islam, no job, residing at Jalan Wijaya Lrg 2 No.4 Rt 005 Rw 008, Lalabata District, Soppeng Regency, after this referred to as Petitioner II. They were married in 1970 in Hulo Village, West Sinajai sub-district, Sinjai Regency. Married by a Hulo village priest named Pangka and the guardian is the biological father of Pemohan II named Dandi and witnessed by two witnesses each named Hela and Dullah with the dowry of one plot. The applicant's marriage has fulfilled the requirements and is in harmony with the marriage, and there is no prohibition for them to carry out the marriage. Petitioner I is a member of the Veteran Republic of Indonesia following the Decree Number: Skep.32 / M / X / 2009 dated October 22, 2009. However, in the marriage, the applicants never had a marriage book. Based on this reason, they submitted a request to the Watansoppeng Religious Court to obtain a decision to use the complete documents further to obtain elderly veteran benefits and other rights at the Taspen office. Furthermore, the Religious Courts through decision Number: 137 /Pdt.P/2016/PASop stipulates:

1. To grant the petitioners' petition

2. Set the Petitioner I (Amiruddin bin Anar) marriage and Petitioner II (Bumbeng Binti Dandi), which took place in 1970 in Hulo Village, West Sinjai District, Sinjai Regency, is legal according to law.

3. Charged the applicant to pay a court fee of Rp. 211,000.00 (two hundred and eleven thousand rupiah).

In the verdict, the Panel of Judges in its consideration is appointed as follows:

- Considering that the main problem, in this case, is that the petitioners submitted a request for marriage because the applicants claimed to have married according to Islamic law in 1970 married by the imam of Hulo village to the marriage guardian of Petitioner II's biological father and the dowry in the form of a rice field one plot. There is no obstacle for them to marry according to Islamic law and marriage laws. However, the applicants never had a marriage book.

- Considering, whereas, to prove the petition's arguments, the applicants have submitted written evidence and two witnesses who have given testimony under oath. The testimonies of each witness correspond and are related to one another.

- Considering, whereas based on this evidence, facts have been found that Petitioner I and Petitioner II are husband and wife, whose marriage was carried out in 1970 in Hulo Village, West Sinjai District, Sinnjai Regency. So far, living together and living in harmony have even been blessed with five children, and between them, there has never been a divorce until now. Whereas Petitioner I is a veteran member of the Republic of Indonesia and Petitioner II is the only wife of Petitioner I, the applicant needs the 
legalization of marriage to take care of veteran allowances and other rights Taspen office.

- Considering, whereas based on the considerations above, Petitioner I's petition to declare his marriage to Petitioner II valid, must be declared proven grounded or legally based, and therefore following the provisions of Article 7 paragraph (3) letter (d) and e) Compilation of Islamic Law, the Petitioners' petition should be granted.

- Considering that because this case was about a petition (volunteering), Petitioner I and Petitioner II borne the case's cost.

Based on these facts, the panel of judges believes that although the applicant's evidence did not receive an explanation from the marriage guardian and who acted as witnesses in the marriage, it is indeed very difficult to prove it because the incident occurred around forty-six years ago. Then, however, with the facts found in the trial, the petitioners' petition deserves to be granted.

\section{Case II: Case Number: 15 / P / 2016 / PA.Sop}

Hj. Marawijah Binti Lamttuwa, 70 years old, Islam, a housewife, residing at BTN Antara Blok C5 Number 7, Tamalanrea Village, Tamalanrea District, Makassar City, after this referred to as the Petitioner. Teah launched his marriage on September 1, 1955, with Anwar Badiu bin Andi Baso in Pare-Pare District, married the Imam of Pare-Pare District. The guardian was the Petitioner's biological father, Lamttuwa, with a dowry of Rp. 27.50, witnessed by two witnesses, each named H. A. Gafur, and one person has forgotten their name by the applicant. The applicant's marriage with Anwar Badiu bin Andi Baso has met the requirements and rules of marriage, following the applicable laws and regulations. There is no prohibition for them to marry. Since the applicant's marriage with Anwar Badiu bin Andi Baso, there has never been a divorce until Anwar Badiu bin Andi Baso passed away on January 4, 2011. Anwar Badiu bin Andi Baso during his lifetime, was a TNI Army officer. Based on the reasons above, the applicant submitted a request to the Religious Court to obtain a marriage stipulation (itsbat nikah) which could then be used to complete the widow's pension documents and other rights Taspen office. Furthermore, the Religious Courts through decision Number: 15 / P / 2016 / PA.

1. To grant the applicant's request

2. State the applicant's (Hj. Marawijah Binti Lamattuwa) marriage with the man Anwar Badiu bin Andi Baso, held on September 1, 1953, Pare-Pare Regency, is legal according to law.

3. Charged the applicant a fee of Rp. 141,000, - (one hundred and forty-one rupiah).

In the verdict, the Panel of Judges, in its consideration, stated as follows:

- Considering, whereas the main problem in this case is that the applicant submitted a request for marriage marriage on the grounds that the applicant and Anwar Badiu bin Andi Baso had married according to Islamic law which was held on September 1, 1953 in Pare-Pare Regency. Married by the Imam of Pare-Pare District to the marriage guardian of the applicant's biological father named Lamattuwa and a dowry of Rp. 27.50 witnessed by two witnesses and there is no prohibition for them to marry according to Islamic law and the Marriage Law. However, the applicant never has my copy of the Marriage Certificate, only a marriage certificate.

- Considering, whereas in order to prove the arguments of the petition, the applicant has submitted written evidence and two witnesses who were present at the wedding of the applicant with Anwar Badiu bin Andi Baso and have provided testimony under oath, in which the testimony of each witness corresponds and relate to one another. 
- Considering, whereas based on the applicant and witnesses' statements, it turns out that the Petitioner and Anwar Baddiu bin Andi Baso have been blessed with ten children, and 2 of them died. Whereas since the applicant and her husband became husband and wife, no one has ever objected to the applicant's status with Anwar Badiu bin Andi Baso as husband and wife. There has never been a divorce until her husband died.

- Considering, whereas evidence P5, a Marriage Certificate, can be used as preliminary evidence of the applicant's marriage to Anwar Badiu bin Andi Baso, held on September 1, 1953, Pare-Pare.

- Considering, whereas based on the applicant's admission, the applicant and Anwar Badiu bin Andi Baso are related by blood but not according to that which could prevent the applicant's marriage to her husband.

- Considering that based on the testimony of witnesses and evidence P2, P3, and P4, it turns out that the Petitioner's husband (Anwar Badiu bin Andi Baso) is a retired Army Armed Forces retired Army who still gets a pension salary, and it turns out that the name of Marawijah as a wife and Anwar Badiu bin Andi Baso who are still receiving visits as wives, who are now domiciled in Makassar.

Concerning the above description, it turns out that marriages without a marriage certificate can be requested for marriage approval or marriage certificate at the Religious Court but must comply with existing laws and procedures, including presenting witnesses at the trial and showing evidence. It is existing so that it can become a judge's consideration in making a decision. Even though the evidence is still considered minimal, if, according to the judge, the evidence has met the formal requirements, then the evidence can become valid evidence. From the case example above, it is clear that the marriage ceremony carried out at the Watansoppeng Religious Court is following the provisions of the applicable laws, namely Law Number 1 of 1974 and the Compilation of Islamic Law. This can be proven by looking at the existing facts and explanations from witnesses and evidence, that in the two cases above carried out a marriage before Law Number 1/1974 concerning marriage came into effect, and following what is regulated in Article 7 paragraph (3) letter (d) Compilation of Islamic Law, as well as such marriages do not have the prohibition of marriage as regulated in Article 8 to Article 10 of Law Number 1/1974 jo. Articles 39 to 44 Compilation of Islamic Law. In Islam, marriage is a form of worship because it is an order from Allah SWT and the Prophet. Because of the importance of this marriage issue, it is highly recommended to do it as well as possible and comply with the prevailing laws and regulations, like just about an under-the-hand marriage or sirri marriage which is a problem in Indonesian society. Marriage is not be forbidden or illegitimate marriage because it has met the requirements and harmonious marriage and is legal according to Islamic law. It's just that the marriage has not been recorded / not recorded, so it has no legal force.

\subsection{Basic Consideration of Judges in Deciding the Itsbat Marriage Case at the Watansoppeng Religious Court}

Judges have the freedom to decide the cases they are judging on. Judges are officials who exercise judicial power free from interference by other state powers, in other cases, in this case, the government. He must have the strong personal integrity to use his freedom as an executive officer of judicial power. The judges' considerations in deciding a case at the Religious Court are based on a legal perspective, namely statutory provisions, and from a non-legal perspective, namely by looking at the arguments of a lawsuit or petition. In general, the basis for consideration of judges in deciding marriage legalization cases submitted to the Religious Court, which refers to Article 7 Paragraph (3) Compilation of 
Islamic Law, Marriage Intersection can be submitted to the Religious Court which regulates matters relating to:

1. There is a marriage in the framework of a divorce settlement;

2. Loss of marriage certificate;

3. There are doubts about whether or not one of the conditions of marriage is valid;

4. The existence of marriages that occurred before the enactment of Law Number 1/1974;

5. Marriage is carried out by those who do not have a marriage impediment, according to Law Number 1/1974.

This means that in the case of a marriage that does not have the legal validity of a marriage or a marriage that does not yet have permanent legal force, the Itsbat Nikah can be submitted as long as all the terms and conditions of marriage have been fulfilled. Following the provisions of Islamic law and state law, it can apply for a marriage certificate. In the determination of the request for a marriage license, it refers to the Compilation of Islamic Law provisions and Law Number 1/1974. In the request for a marriage permit, the judge considers the aspects of clarity of the facts and legal certainty. According to M. Hatta (Judge of the Watansoppeng Religious Court), the issue of marriage inheritance submitted to the religious court is resolved by referring to the compilation rules of Islamic law article 7 paragraph (3). Then, by looking at the facts in the trial derived from each of the applicants' statements and the testimonies of both witnesses, and evidence of letters submitted by Petitioner I and Petitioner II, which can be used as a reference for deciding the marriage legalization case.

\section{Conclusion}

Itsbat Marriage legalization or marriage legalization carried out at the Watansoppeng Religious Court has been carried out properly and correctly because it follows the applicable laws and regulations, in this case, Law Number 1 of 1974 concerning Marriage and the Compilation of Islamic Law as well. Following the book of Fiqh, which is the source of the Compilation of Islamic Law, which serves as a guide for judges in examining and adjudicating cases submitted to the Religious Court. This can be seen from the procedures for implementing the marriage certificate and the judges' considerations to the verdict. The basis for consideration of judges in deciding marriage cases or legalizing marriage refers to the provisions of statutory regulations, namely Article 7 paragraph (3) Compilation of Islamic Law. Apart from referring to the aforementioned statutory regulations, trial facts are also contained in the trial that is sourced from the applicants' statements, the statements of each witness, and evidence of the letters submitted. The need to provide information and counseling to the community on an incentive basis. Counseling about the contents of Law Number 1 of 1974 concerning marriage, counseling on the importance of marriage registration for life to come, especially for children and the assets obtained in marriage. This counseling is given to all levels of society, especially rural communities, both married and unmarried. The purpose of marriage is to form an eternal family based on God Almighty. Legal practitioners need to be more careful in examining marriage cases, especially regarding applications for marriage certificates, where judges must provide adequate legal considerations to fulfill a sense of justice, benefit, and certainty. In this regard, judges need to consider marriage terms and conditions in submitting a marriage certificate that has been fulfilled and is considered valid and appropriate to apply for iitsbat marriage. 


\section{References}

Ahmad, Rofiq. (2005). Hukum Islam di Indonesia. Manajemen PT. Grafika Persada: Jakarta.

Daud, Ali M. (2004). Hukum Islam, Pengantar Ilmu Hukum dan Tata Hukum Islam di Indonesia, Edisi II. Balai Pustaka: Jakarta.

Departemen Pendidikan dan Kebudayaan RI, Kamus Besar Bahasa Indonesia, Edisi II. Balai Pustaka: Jakarta.

Djalil, Basiq. (2006). Peradilan Agama di Indonesia. Kencana: Jakarta.

Djubaidah, Neng. (2010). Pencatatan Perkawinan dan Perkawinan Tidak di Catatkan. Sinar Grafika: Jakarta.

Hadikusuma, Hilman. (2007). Hukum Perkawinan Indonesia. Sumber Sari Indah: Bandung. Hamid, Arifin. (2011). Hukum Islam Perspektif Keindonesiaan (Sebuah Pengantar dalam Memahami Realitasnya di Indonesia). UMITOHA: Makassar

Hamid, Zahry. (2008). Pokok-Pokok Hukum Perkawinan Islam dan Undang-Undang Perkawinan di Indonesia. Bina Cipta: Yogyakarta.

Harahap, Yahya, M. (2004). Hukum Acara Perdata. Sinar Grafika: Jakarta.

Jamaluddin. (2018). AL Ghazali's View Regarding to the Witness in Islamic Wedding Ceremony. Budapest International Research and Critics Institute-Journal (BIRCIJournal). P. 01-10.

Purba, N. and Mulyadi. (2020). Subordinate Clauses Used in Anak Boru Sanina in Simalungun Wedding Ceremony. Lakhomi Journal: Scientific Journal of Culture. P. 23-35.

Ramulyo, Idris M. (2004). Hukum Perkawinan Islam, Suatu Studi Analisis dari undangUndang Nomor 1 Tahun 1974 dan Kompilasi Hukum Islam. PT. Bumi Aksara: Jakarta.

(2006). Hukum Perkawinan, Hukum Kewarisan, Hukum Acara Peradilan Agama dan Zakat Menurut Hukum Islam. Sinar Grafika: Jakarta

Soetojo, Prawirohamidjojo. (2006). Pluralisme dalam Perundang-Undangan Perkawinan Di Indonesia. Airlangga University Press: Surabaya

Sudarsono. (2005). Hukum Perkawinan Nasional. Rineka Cipta: Jakarta

Suyuti, Mustafa. W. (2003). Nikah Sirri Antara Kenyataan dan Kepastian Hukum. DITBINBAPERA Islam: Jakarta Pusat.

Syarifuddin, Amir. (2009). Hukum Perkawinan Islam di Indonesia, Antara Fiqih Munakahat dan Undang-Undang Perkawinan. Kencana: Jakarta

Triwulan Titik, T. (2008). Hukum Perdata Dalam Sistem Hukum Nasional. Kencana: Jakarta

Usman, Rachmadi. (2008). Aspek-Aspek Hukum Perorangan dan Kekeluargaan di Indonesia. Sinar Grafika: Jakarta

Undang-undang Nomor 1 Tahun 1974 tentang Perkawinan

Undang-Undang Nomor 7 Tahun 1989 tentang Peradilan Agama

Undang-undang Nomor 3 Tahun 2006 tantang Perubahan Atas Undang- undang Nomor

7 Tahun 1989 tentang Peradilan Agama

Undang-undang Nomor 48 Tahun 2009 Tentang Kekuasaan Kehakiman

Undang-undang Nomor 35 Tahun 1999 tentang Perubahan Atas Undang- Undang Nomor 14 Tahun 1970 tentang Ketentuan-Ketentuan Pokok Kekuasaan Kehakiman

Undang-undang Nomor 50 tahun 2009 tentang Perubahan Kedua Atas UndangUndang Nomor 1 Tahun 1974

Instruksi Presiden Nomor 1 Tahun 1991 tentang Kompilasi Hukum Islam 